\title{
Synthesis and Properties of Polyesters from Waste Grapeseed Oil: Comparison with Soybean and Rapeseed Oils
}

\author{
A. J. Clark $^{1}$ (I) A. H. Ross ${ }^{1}$ - S. A. F. Bon ${ }^{1}$
}

Published online: 22 November 2016

(c) The Author(s) 2016. This article is published with open access at Springerlink.com

\begin{abstract}
The aim of this study was to investigate the application of grapeseed oil, a waste product from the wine industry, as a renewable feedstock to make polyesters and to compare the properties of these materials with those derived from soybean and rapeseed oils. All three oils were epoxidized to give renewable epoxy monomers containing between 3.8 and 4.7 epoxides per molecule. Polymerisation was achieved with cyclic anhydrides catalysed by 4-methyl imidazole at 170 and $210^{\circ} \mathrm{C}$. Polymers produced from methyl tetrahydrophthalic anhydride (Aradur917 ${ }^{\circledR}$ ) had greater tensile strength and Young's Modulus (tensile strength $=12.8 \mathrm{MPa}$, Young's Modulus = $1005 \mathrm{MPa}$ for grapeseed) than methyl nadic anhydride (MNA) derived materials (5.6 and $468 \mathrm{MPa}$ for grapeseed) due to increased volume of MNA decreasing crosslink density. Soybean and grapeseed oils produced materials with higher tensile strength (5.6-29.3 MPa) than rapeseed derived polyesters (2.5-3.9 MPa) due to a higher epoxide functionality increasing crosslinking. $T_{\mathrm{g}}$ 's of the polyesters ranged from -36 to $62{ }^{\circ} \mathrm{C}$ and mirrored the trend in epoxide functionality with grapeseed producing higher $T_{\mathrm{g}}$ polymers ( -17 to $\left.17^{\circ} \mathrm{C}\right)$ than soybean $\left(-25\right.$ to $\left.6^{\circ} \mathrm{C}\right)$ and rapeseed $(-36$ to $-27^{\circ} \mathrm{C}$ ). Grapeseed oil showed similar properties to soybean oil in terms of $T_{\mathrm{g}}$, thermal degradation and Young's Modulus but produced polymers of lower tensile strength.
\end{abstract}

A. J. Clark

a.j.clark@warwick.ac.uk

A. H. Ross

A.Ross.3@warwick.ac.uk

S. A. F. Bon

s.bon@warwick.ac.uk

1 Department of Chemistry, University of Warwick, Coventry CV4 7AL, UK
Therefore grapeseed oil would only be a viable substitute for soybean for low stress applications or where thermal properties are more important.

Keywords Grapeseed oil · Polyester networks · Mechanical properties - Thermal properties - Crosslink density

\section{Introduction}

In the modern world demand for materials is ever increasing, however as supplies of natural resources such as crude oil are becoming limited [1] the use of renewable feedstocks becomes ever more attractive. Vegetable oils are generating much interest as a feedstock for polymers, this is partly because they are environmentally friendly, have high purity, are annually renewable [2] and their relative ease of functionalization provides materials with useful thermal and mechanical properties [3-14]. Vegetable oils have also generated interest for their structure, with the commonest oils being triglycerides made mainly from five fatty acids; oleic (C18:1), linoleic (C18:2), linolenic (C18:3), stearic (C18:0) and palmitic (C16:0). These oils, therefore containing varying amounts of carbon-carbon double bonds, which can easily be modified making them interesting from a chemical point of view [3-14].

Chemical modifications of vegetable oils include transesterification (e.g. for biofuels) [1, 15], hydrogenation (for margarine synthesis) $[16,17]$ and modification of the double bonds, one of the most common being epoxidation $[12,18]$. Epoxidized oils have a variety of uses including as resins [19], as precursors of polyols for polyurethane synthesis $[14,20]$ and for coatings [21]. 
Epoxidized soybean oil (Fig. 1) is one of the most common vegetable oil feedstocks used in industry, traditionally it has been used as a plasticizer for PVC [22, 23], as well as for producing polyesters from anhydrides [24-26].

Thermosetting plastics are polymers formed from a liquid starting material that irreversibly lead to a solid material upon curing (polymerisation). The most common thermosets are derived from epoxide monomers and cyclic anhydrides and copolymerise via ring-opening of the epoxides to give crosslinked polyesters (epoxy resins). Epoxidized soybean oil (ESBO) is an ideal candidate as it contains multiple epoxide groups that allow for a highly crosslinked polymer network. Typically, ESBO monomers are blended with commercial petrochemical epoxides, such as bisphenol A diglycidyl ether (BADGE), and reacted with anhydrides, such as maleic anhydride (MA), to give polyesters (epoxy resins). Usually an increase in renewable ESBO content leads to greater flexibility in the polymer with a loss in tensile strength (tensile strength; 100\% $\mathrm{BADGE} / \mathrm{MA}=70 \mathrm{MPa}, \quad 100 \% \quad \mathrm{ESBO} / \mathrm{MA}=36 \mathrm{MPa})$ [24]. Unfortunately, replacing petrochemical epoxides (typically containing terminal epoxides) with less reactive plant oil derived internal epoxides leads to increases in cure temperatures by as much as $40^{\circ} \mathrm{C}$ [25]. Properties of the final plastic are affected by the stoichiometric ratio of epoxide to anhydride functional groups, with values greater or less than the optimum 1:1 ratio leading to a decrease in flexural modulus and hardness of materials due to incomplete curing of the epoxide [26].

Grapeseed oil has a similar number of alkenes per molecule of triglyceride as soybean oil and both contain linoleic acid as the most abundant fatty acid chain [29, 30] followed by oleic acid (Table 1). Grapeseed oil can be extracted from the residue remaining after wine making, the pomace, containing the skin, stems and seeds [31]. From $100 \mathrm{~kg}$ of grapes it is possible to extract $400 \mathrm{~g}$ of oil [32] and with worldwide production of grapes at 67 million tonnes in 2012 [33] this gives a potential of 268,000 tonnes of grapeseed oil per year. The estimated production of epoxidised soybean oil is 200,000 tonnes per year [34], so in terms of volume the waste product grapeseed oil has the potential to replace or augment the food crop soybean oil.

In this paper we report the epoxidation of three plant oils, grapeseed oil, soybean oil and rapeseed oil followed

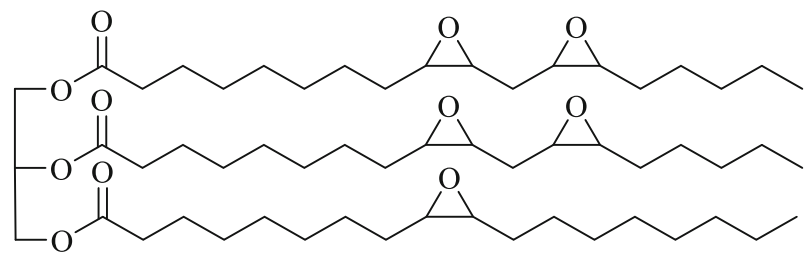

Fig. 1 Epoxidised soybean oil (ESBO)
Table 1 Fatty acid composition and double bond number of vegetable oils used in this study

\begin{tabular}{lcccccc}
\hline Oil & $\mathrm{C}=\mathrm{C}^{\mathrm{a}}$ & \multicolumn{4}{c}{ \% Fatty acids $^{\mathrm{b}}$ (chain length: $\mathrm{C}=\mathrm{C}$ bond) } \\
\cline { 3 - 7 } & & $(16: 0)$ & $(18: 0)$ & $(18: 1)$ & $(18: 2)$ & $(18: 3)$ \\
\hline Grapeseed & 4.8 & 7.4 & 3.9 & 15.6 & 72.2 & 0.3 \\
Soybean & 4.4 & 10.6 & 4.0 & 23.3 & 53.7 & 7.6 \\
Rapeseed & 3.8 & 4.1 & 1.8 & 60.9 & 21.0 & 8.8 \\
\hline
\end{tabular}

${ }^{\mathrm{a}}$ Calculated from ${ }^{1} \mathrm{H}$ NMR analysis

b From FAME analysis [27, 28]

by the polymerisation of the epoxidized oils by cyclic anhydrides methyl tetrahydrophthalic anhydride (Aradur917 ${ }^{\circledR}$ ) and methyl nadic anhydride (MNA). The thermal and mechanical properties of the resulting polymers are analysed and a comparison is made to ascertain the viability of waste grapeseed oil as a substitute for soybean oil in anhydride cured epoxy resins.

\section{Experimental}

\section{Materials}

Soybean, rapeseed and grapeseed oils were purchased commercially and used without further purification. Aradur $917^{\circledR}$ was provided by the Huntsman Corporation and other consumables were purchased from Sigma-Aldrich and were used as purchased.

\section{Measurements}

\section{NMR Spectroscopy}

${ }^{1} \mathrm{H}$ NMR spectra were recorded with Bruker DPX-300 and DPX-400 Hz machines in $\mathrm{CDCl}_{3}$ as solvent (and $\mathrm{CHCl}_{3}$ as internal standard), chemical shifts are quoted in parts per million and coupling constants $J$ are quoted in $\mathrm{Hz}$.

\section{Fourier Transform Infra-Red (FTIR) Analysis}

Infra-red spectral analysis was performed on a PerkinElmer Avatar 320 FTIR spectrometer with samples as liquid films with absorption maxima recorded in wavenumbers $\left(\mathrm{cm}^{-1}\right)$.

Thermogravimetric Analysis (TGA) and Differential Scanning Calorimetry (DSC)

Calorimetric measurements were made on a Metler Toledo DSC1-Star machine with a heating rate of $10{ }^{\circ} \mathrm{C} / \mathrm{min}$. The glass transition temperatures were taken as the midpoint of 
the transition in heat capacity. Thermal stability was studied on a Metler Toledo DSC1-Star instrument with a heating rate of $10^{\circ} \mathrm{C} / \mathrm{min}$ and a temperature range of $25-600{ }^{\circ} \mathrm{C}$. The initial weight of the samples was approximately $10 \mathrm{mg}$. For both measurements standard $40 \mu \mathrm{L}$ aluminium pans were used and the atmosphere was air.

\section{Mechanical Properties}

Tensile testing was performed on an Instron 3800R following BS EN ISO 527-2. A $1 \mathrm{KN}$ load cell was used with an extension rate of $2 \mathrm{~mm} / \mathrm{min}$, the environment was kept at $20{ }^{\circ} \mathrm{C}$. Results are quoted as an average of six tests.

\section{Swelling Test}

Swelling tests were used to determine crosslink density. Approximately $0.2-0.3 \mathrm{~g}$ of polymer sample (with dimentions $10 \mathrm{~mm} \times 10 \mathrm{~mm} \times 3 \mathrm{~mm}$ ) were placed in toluene solvent $(15 \mathrm{~mL})$ for 1 week with daily stirring to obtain equilibrium swelling (constant weight). The swollen samples were removed, blotted dry and weighed, the volume fraction of swelled polymer $v_{p}$ is:

$\frac{1}{v_{p}}=1+\frac{\left(\frac{m_{s}}{m_{0}}-1\right) \cdot \rho_{p}}{\rho_{s}}$

where $\rho_{\mathrm{s}}$ and $\rho_{\mathrm{p}}$ are densities of solvent and polymer respectively and $\mathrm{m}_{\mathrm{s}}$ is the swelled weight and $\mathrm{m}_{0}$ is the initial weight of polymer.

\section{Procedures}

\section{General Procedure for Epoxidation of Vegetable Oils}

Epoxidation was achieved by the method of Petrović [12] and performed on a $200-400 \mathrm{~g}$ scale. The vegetable oil (e.g. grapeseed oil $400 \mathrm{~g}, 0.454 \mathrm{~mol}$ ) was dissolved in toluene $(1 \mathrm{~L})$ and heated to $80{ }^{\circ} \mathrm{C}$. Acetic acid $(13.62 \mathrm{~g}$, $0.5 \mathrm{eq})$ and Amberlite ${ }^{\circledR}$ IR120 (100 g, $\left.25 \mathrm{wt} \%\right)$ were added followed by dropwise addition of hydrogen peroxide solution $(35 \%, 352 \mathrm{~mL}, 8 \mathrm{eq})$. The reaction was stirred overnight at $80{ }^{\circ} \mathrm{C}$ in air. After completion the reaction was cooled, washed with water $(3 \times 500 \mathrm{~mL}), \mathrm{NaCl}$ (sat, $2 \times 100 \mathrm{~mL}$ ) and dried using $\mathrm{MgSO}_{4}$. The solvent was removed in vacuo to yield a green tinted oil. (421.8 g, $97 \%)$.

\section{Epoxidation of Grapeseed Oil (EGSO)}

Green tinted oil, $421.8 \mathrm{~g}$ (97\%). ${ }^{1} \mathrm{H}$ NMR $(400 \mathrm{MHz}$, $\left.\mathrm{CDCl}_{3}\right) \delta 5.29-5.23(\mathrm{~m}, 1 \mathrm{H}), 4.30(\mathrm{dd}, J=11.9,4.3 \mathrm{~Hz}$,
2H), $4.15(\mathrm{dd}, J=11.9,5.9 \mathrm{~Hz}, 2 \mathrm{H}), 3.15-3.04(\mathrm{~m}, 4 \mathrm{H})$, $3.01-2.94(\mathrm{~m}, 4 \mathrm{H}), 2.89(\mathrm{~s}, 1 \mathrm{H}), 2.32(\mathrm{t}, J=7.5 \mathrm{~Hz}, 6 \mathrm{H})$, $1.80-1.76(\mathrm{~m}, 1 \mathrm{H}), 1.73(\mathrm{t}, J=6.0 \mathrm{~Hz}, 3 \mathrm{H}), 1.62(\mathrm{~s}, 6 \mathrm{H})$, $1.56-1.43(\mathrm{~m}, 18 \mathrm{H}), 1.34(\mathrm{~d}, J=2.2 \mathrm{~Hz}, 30 \mathrm{H}), 1.26(\mathrm{~s}$, $12 \mathrm{H}), 0.89(\mathrm{t}, J=7.3 \mathrm{~Hz}, 9 \mathrm{H}) . \quad \mathrm{IR}\left(\mathrm{cm}^{-1}\right) 2924,2854$ $\left(v_{\mathrm{CH} 2 / \mathrm{CH} 3}\right), 1740 \quad\left(v_{\mathrm{C}=\mathrm{O}}\right), 822\left(v_{\text {epox }}\right)$. ESI-MS: 997.7 $[\mathrm{M}+\mathrm{Na}]^{+}(3 \times 18: 2), 983.7[\mathrm{M}+\mathrm{Na}]^{+}(1 \times 18: 1$, $2 \times 18: 2), 696.7[\mathrm{M}+\mathrm{Na}]^{+}(2 \times 18: 1,1 \times 18: 2), 955.7$ $[\mathrm{M}+\mathrm{Na}]^{+}(3 \times 18: 1), 941.7[\mathrm{M}+\mathrm{Na}]^{+}(1 \times 18: 0$, $2 \times 18: 1)$.

\section{Epoxidation of Soybean Oil (ESBO)}

Yellow/green tinted oil, $314.7 \mathrm{~g} \quad(96 \%) .{ }^{1} \mathrm{H} \quad \mathrm{NMR}$ $\left(300 \mathrm{MHz}, \mathrm{CDCl}_{3}\right) \delta 5.31-5.21(\mathrm{~m}, 1 \mathrm{H}), 4.31(\mathrm{dd}$, $J=11.9,4.2 \mathrm{~Hz}, 2 \mathrm{H}), 4.14(\mathrm{dd}, J=11.9,5.9 \mathrm{~Hz}, 2 \mathrm{H})$, 3.22-3.02 (m, 4H), $2.97(\mathrm{~s}, 3 \mathrm{H}), 2.89(\mathrm{~s}, 2 \mathrm{H}), 2.32(\mathrm{t}$, $J=7.7 \mathrm{~Hz}, 6 \mathrm{H}), 1.75(\mathrm{dt}, J=15.1,6.3 \mathrm{~Hz}, 4 \mathrm{H}), 1.62(\mathrm{~s}$, $6 \mathrm{H}), 1.50(\mathrm{~d}, J=4.1 \mathrm{~Hz}, 18 \mathrm{H}), 1.34(\mathrm{~s}, 22 \mathrm{H}), 1.26(\mathrm{~s}$, 20H), $0.89(\mathrm{t}, J=6.9 \mathrm{~Hz}, 9 \mathrm{H}) . \mathrm{IR}\left(\mathrm{cm}^{-1}\right): 2923,2854$ $\left(v_{\mathrm{CH} 2 / \mathrm{CH} 3}\right), 1741\left(v_{\mathrm{C}=\mathrm{O}}\right), 823\left(v_{\text {epox }}\right)$. ESI-MS: 1011.7 $[\mathrm{M}+\mathrm{Na}]^{+}(1 \times 18: 3,2 \times 18: 2), \quad 997.7 \quad[\mathrm{M}+\mathrm{Na}]^{+}$ $(3 \times 18: 2), 696.7[\mathrm{M}+\mathrm{Na}]^{+}(2 \times 18: 1,1 \times 18: 2), 955.7$ $[\mathrm{M}+\mathrm{Na}]^{+}(3 \times 18: 1), 941.7 \quad[\mathrm{M}+\mathrm{Na}]^{+}(1 \times 18: 0$, $2 \times 18: 1)$.

\section{Epoxidation of Rapeseed Oil (ERSO)}

Cream waxy solid, $203.1 \mathrm{~g}$ (95\%). ${ }^{1} \mathrm{H}$ NMR $(300 \mathrm{MHz}$, $\left.\mathrm{CDCl}_{3}\right) \delta 5.26-5.17(\mathrm{~m}, 1 \mathrm{H}), 4.25(\mathrm{dd}, J=11.9,4.3 \mathrm{~Hz}$, $2 \mathrm{H}), 4.09(\mathrm{dd}, J=11.9,5.9 \mathrm{~Hz}, 2 \mathrm{H}), 3.18-2.98(\mathrm{~m}, 2 \mathrm{H})$, $2.93(\mathrm{~s}, 2 \mathrm{H}), 2.85(\mathrm{~s}, 4 \mathrm{H}), 2.27(\mathrm{t}, J=7.5 \mathrm{~Hz}, 6 \mathrm{H})$, $1.76-1.65(\mathrm{~m}, 2 \mathrm{H}), 1.57(\mathrm{~s}, 6 \mathrm{H}), 1.44(\mathrm{~s}, 18 \mathrm{H}), 1.28(\mathrm{~s}$, $25 \mathrm{H}), 1.23(\mathrm{~s}, 15 \mathrm{H}), 1.20(\mathrm{~s}, 8 \mathrm{H}), 0.83(\mathrm{t}, J=6.7 \mathrm{~Hz}, 9 \mathrm{H})$. IR $\left(\mathrm{cm}^{-1}\right) 2923,2854\left(v_{\mathrm{CH} 2 / \mathrm{CH} 3}\right), 1741\left(v_{\mathrm{C}=\mathrm{O}}\right), 824\left(v_{\text {epox }}\right)$. ESI-MS: $1011.7[\mathrm{M}+\mathrm{Na}]^{+}(1 \times 18: 3,2 \times 18: 2), 997.7$ $[\mathrm{M}+\mathrm{Na}]^{+}(3 \times 18: 2), 983.7[\mathrm{M}+\mathrm{Na}]^{+}(1 \times 18: 1$, $2 \times 18: 2), 696.7[\mathrm{M}+\mathrm{Na}]^{+}(2 \times 18: 1,1 \times 18: 2), 955.7$ $[\mathrm{M}+\mathrm{Na}]^{+}(3 \times 18: 1)$.

\section{General Procedure for Polymerisation of Epoxy Oils}

Polymerisation was performed on a $16 \mathrm{~g}$ scale. The epoxidised vegetable oil and 4-methyl imidazole $(0.16 \mathrm{~g}$, $1 \mathrm{wt} \%$ ) were combined and heated to $40{ }^{\circ} \mathrm{C}$ to aid dissolving of the 4-methyl imidazole (4-MI). The mixture was degassed for 10 min under high vacuum and rapid stirring. The anhydride was added in varying amounts to give the required epoxide: anhydride (E:A) mol ratio and the mixture was further degassed for $20 \mathrm{~min}$. The reaction mixture was poured into an aluminium 'dog bone' mould lined with silicone release spray and heated at $170{ }^{\circ} \mathrm{C}$ (Aradur $917^{\circledR}$ ) or $210{ }^{\circ} \mathrm{C}$ (MNA) for $1 \mathrm{~h}$. 


\section{Results and Discussion}

\section{Composition of Plant Oils}

The vegetable oils used in this investigation are listed in Table 1 with their fatty acid compositions and the average number of double bonds per molecule. These oils are mainly formed from palmitic $\mathrm{P}$ (16:0), stearic $\mathrm{S}$ (18:0), oleic O (18:1), linoleic L (18:2) and linolenic Ln (18:3) acids. The oils are listed in order of unsaturation expressed as the average number of $\mathrm{C}=\mathrm{C}$ double bonds per molecule. The $\mathrm{C}=\mathrm{C}$ number was calculated by ${ }^{1} \mathrm{H} \mathrm{NMR}$ analysis from the integrated area under the alkene peaks at $5.35 \mathrm{ppm}$ compared to the terminal methyl triplet at $0.89 \mathrm{ppm}$ (Fig. 2). The level of unsaturation is important as this determines the epoxide level after epoxidation. The number of epoxide groups per molecule will govern the level of crosslinking, which will ultimately affect the physical properties of the polyesters.

\section{Epoxidation of Plant Oils}

The vegetable oils were epoxidised following the method of Petrovic [12], using acetic acid, an ion exchange resin (Amberlite $^{\circledR}$ IR120) and hydrogen peroxide in toluene (Fig. 3). The reactions were performed at $80{ }^{\circ} \mathrm{C}$ and were monitored by ${ }^{1} \mathrm{H}$ NMR looking for disappearance of the alkene peaks at around $5.35 \mathrm{ppm}$ and the appearance of epoxide peaks at 2.8-3.1 ppm.

The epoxidised plant oils derived from grapeseed (EGSO), soybean (ESBO) and rapeseed oil (ERSO) were produced in high yields (95-97\%) and purity, and were used without further purification. In an attempt to reduce costs and overall environmental impact of the epoxidation procedure the reaction with grapeseed oil was attempted without solvent [35]. Unfortunately, while the reaction was

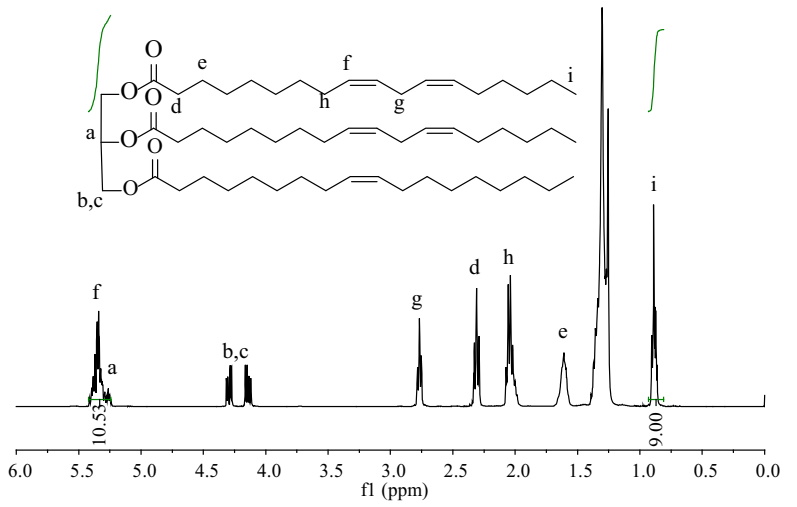

Fig. $2{ }^{1} \mathrm{H}$ NMR $\left(400 \mathrm{MHz}, \mathrm{CDCl}_{3}\right)$ of grapeseed oil

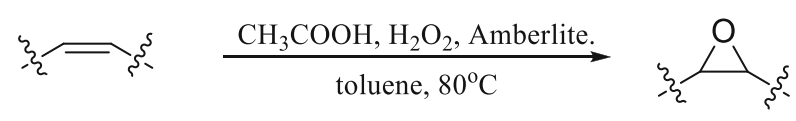

Fig. 3 Epoxidation reaction of unsaturated plant oils

complete after only $6 \mathrm{~h}$ the lower yield of EGSO (86\%) was disappointing.

The epoxidized oils used in this study (EGSO, ESBO and ERSO) are mixtures of different triglyceride molecules containing statistical mixtures of epoxidized fatty ester derivatives. It was possible to identify the different triglyceride components in these mixtures and their level of epoxidation by electrospray mass spectrometry, Fig. 4.

The profiles for both EGSO and ESBO show significant contributions (997.7 amu) for the triglyceride made from three fully epoxidized linoleic chains (6-epoxides) while the spectrum for ERSO shows the main triglycerides contain mixed oleic and linoleic epoxidized chains (at 969.7 and $983.7 \mathrm{amu}$ ), with 4 and 5 epoxides respectively. Consequently, we would expect polyesters prepared from ERSO to have lower crosslinking densities and by analogy lower tensile strengths and $T_{\mathrm{g}}$ 's than materials prepared

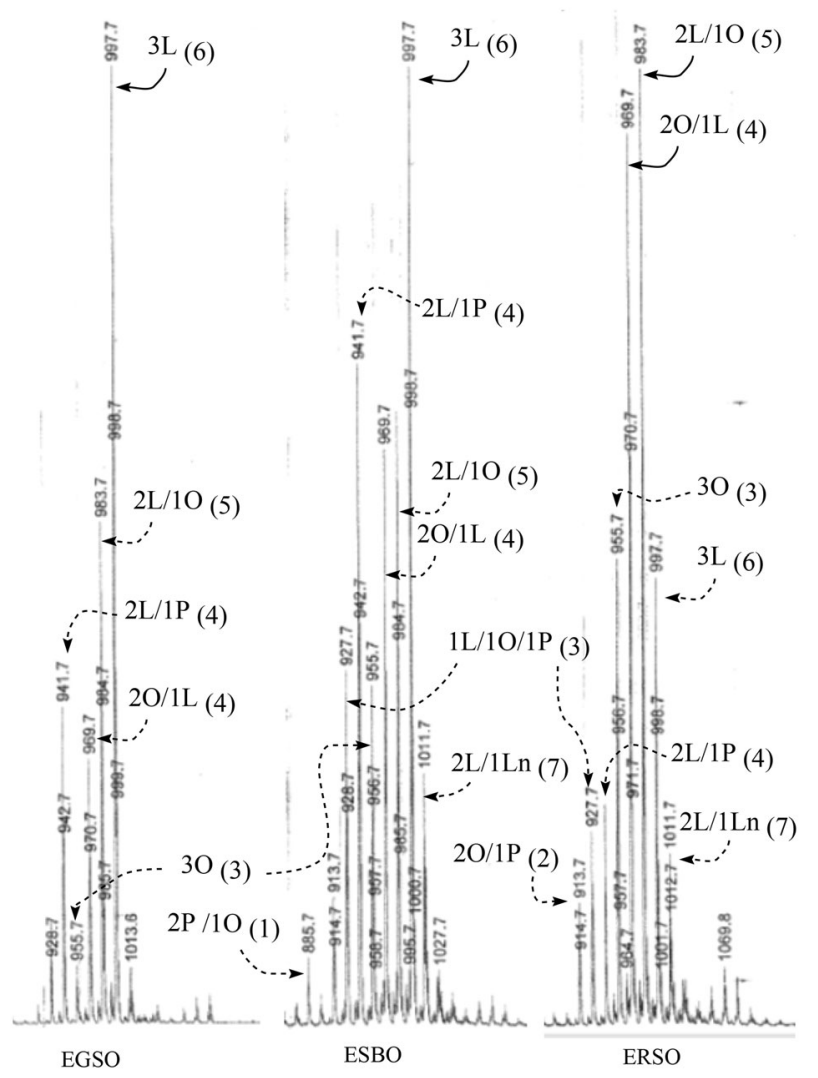

Fig. 4 Electrospray mass spectrometry. Key: $P$ palmitic, $S$ stearic, $O$ oleic, $L$ linoleic, $L n$ linolenic, $(\#$ in brackets $=\#$ of epoxides in triglyceride, \# before letter $=\#$ of that fatty acid chains in triglyceride) 
from ESBO or EGSO. There was little evidence of any ring-opened diol functionalised triglycerides, arising from ring-opening of the epoxides by water.

\section{Copolymerisation of Epoxidized Plant Oils}

We used two hardeners for copolymerisation, methyl tetrahydrophthalic anhydride [36] (marketed by Huntsman as Aradur917 $7^{\circledR}$ ) and methyl-5-norbornene-2,3-dicarboxylic anhydride (methyl nadic anhydride, MNA), Fig. 5.

Polymerizations were investigated for each epoxidized oil with both anhydrides using 4-methyl imidazole (4-MI) as a catalyst. For each epoxidized oil (E)/anhydride (A) combination three different molar ratios (E:A) were investigated providing 18 polymers for analysis, Fig. 5 .

\section{Curing Kinetics}

The epoxidized oils and anhydrides were combined to give epoxide:anhydride functional group ratios (E:A) of 1:1 and 2:1 in line with previous reported work [26]. In addition an equimolar ratio of triglyceride to anhydride was used ( $\sim$ 4:1 E:A ratio depending upon the oil) with the catalyst 4-MI ( $1 \mathrm{wt} \%$ relative to the total reaction mixture). The formulations with a higher E:A ratio would be expected to provide more flexible materials due to the plasticizing effect of the vegetable oil. To analyse curing kinetics and determine an optimal cure temperature, samples of 1:1 E:A mixture of all oils and Aradur917 ${ }^{\circledR}$ were analysed by DSC (Fig. 6). The peak cure temperature $\left(\mathrm{C}_{\mathrm{T}}\right)$ was found to increase inversely with the epoxide number (in brackets) EGSO (4.7) $\mathrm{C}_{\mathrm{T}}=148{ }^{\circ} \mathrm{C}>\operatorname{ESBO}$ (4.4) $\mathrm{C}_{\mathrm{T}}=151^{\circ} \mathrm{C}>\operatorname{ERSO}$ (3.8) $\mathrm{C}_{\mathrm{T}}=155^{\circ} \mathrm{C}$. This correlates to the greater proportion of epoxidized linoleic chains and is in agreement with the trends found by Webster [37] for the polymerization of epoxy sucrose esters and cyclic anhydrides. The cure temperature range was similar to that observed for epoxy resins derived from ESBO and maleic anhydride $\left(\mathrm{C}_{\mathrm{T}}=150{ }^{\circ} \mathrm{C}\right)$ [26]. It was also possible to determine the enthalpy of polymerization from the area under the DSC curve. As expected (for Aradur917 ${ }^{\circledR}$ ) the oils with higher levels of epoxides released more energy during polymerization due to<smiles>CC1=CCC2C(=O)OC(=O)C2C1</smiles>

Aradur917<smiles>CC1=CC2CC1C1C(=O)OC(=O)C21</smiles>

MNA

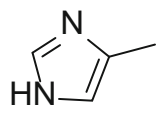

4-MI
Fig. 5 Anhydrides Aradur917 and methyl nadic anhydride (MNA) and catalyst 4-methyl imidazole (4-MI) used in this study

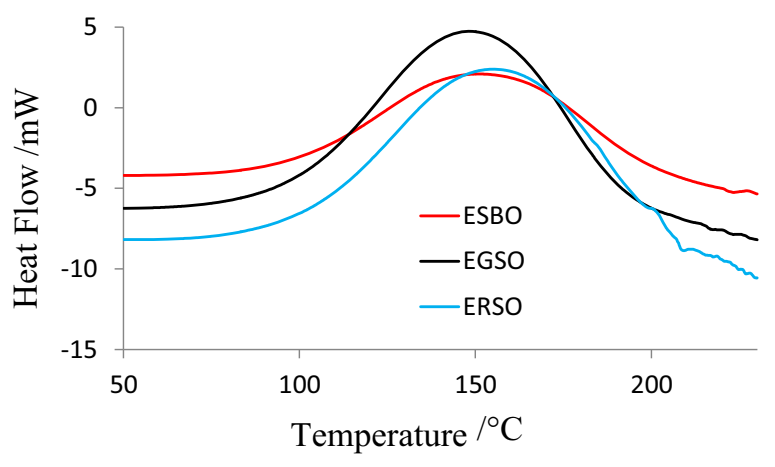

Fig. 6 DSC of curing of EGSO, ESBO and ERSO with Aradur $917^{\circledR}$ (1:1 E:A ratio)

an increased number of crosslinks being formed $\left(\Delta H_{\text {polymerization }}\right.$ EGSO $=218 \mathrm{~J} \mathrm{~g}^{-1}, \quad$ ESBO $201 \mathrm{~J} \mathrm{~g}^{-1}$, ERSO $176 \mathrm{~J} \mathrm{~g}^{-1}$ ). The peak cure temperature for polymers produced using MNA as the anhydride component were substantially higher than Aradur $917^{\circledR}$ but followed the same trend $\left(\right.$ EGSO $203{ }^{\circ} \mathrm{C}>$ ESBO $206{ }^{\circ} \mathrm{C}>$ ERSO $210{ }^{\circ} \mathrm{C}$ )

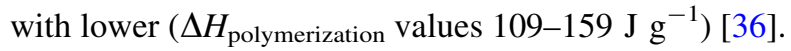

The data shows that a cure temperature of $170{ }^{\circ} \mathrm{C}$ for Aradur $917^{\circledR}$ and $210^{\circ} \mathrm{C}$ for MNA derived polymers would be sufficient for polymerization. DSC measurements of EGSO polymers cured at these temperatures for $1 \mathrm{~h}$ showed no exothermic peaks in their DSC indicating complete curing under these conditions.

\section{Crosslinking Density}

Crosslinking density is an important characteristic of thermoset resins as it governs the physical properties of the polymer network. Typically expressed as mass between crosslinks $\left(\mathrm{M}_{\mathrm{c}}\right)$ or crosslink density $\left(\mathrm{v}_{\mathrm{c}}\right)$ and can be calculated by the Flory-Rehner equation:

$v_{c}=\frac{\rho_{p}}{M_{c}}=\frac{\ln \left(1-V_{p}\right)+V_{p}+\chi V_{p}^{2}}{V_{s} \rho_{p}\left(V_{p}^{\frac{1}{3}}-V_{p} / 2\right)}$

where $V_{p}$ is the volume fraction of swollen polymer, $V_{s}$ is the volume fraction of the solvent and $\chi$ is the polymersolvent interaction parameter which is related to the solubility parameters via:

$\chi=0.34+\frac{V_{s}}{R T}\left(\delta_{1}-\delta_{2}\right)^{2}$

Where $\mathrm{R}$ is the gas constant, $\mathrm{T}$ is temperature and $\mathrm{V}_{\mathrm{s}}$ is the molar volume of the solvent. The calculated crosslink densities are listed in Table 2.

The differences in crosslink densities arise from three factors; the type and amount of anhydride hardener used, and the composition of the epoxidized oil. As expected the crosslinking density is highest when a 1:1 ratio of 
anhydride is used, as all the epoxides can potentially react. With sub-stoichiometric levels of anhydride less epoxides are available to react leading to lower crosslinking points. For example, $v_{c}$ decreases from 32.9 to 23.4 and 12.8 as the hardener ratio decreases from 1:1 to 2:1 and 4.7:1 in EGSO with Aradur $917^{\circledR}$ Table 2. Polymers prepared from MNA generally have lower crosslink densities due to the larger molecular volume of this monomer as a consequence of the bridgehead methylene group, Fig. 7.

Interestingly, the crosslink density does not completely parallel the epoxide value of the oils. With both anhydride hardeners a 1:1 ratio with ESBO gives a more crosslinked structure than EGSO. We believe this phenomenon may be due to the higher linoleic content of EGSO within the triglyceride, where polymerization of one epoxide in the linoleate chain may reduce the free movement of the adjacent epoxide locking it in the network preventing efficient curing. Alternatively, an increased probability of intramolecular reactions between epoxides could occur in EGSO derived polymers lowering the crosslink density of the polymer. FTIR analysis of the cured ESBO and EGSO polymers with Aradur917 ${ }^{\circledR}$ does show some residual epoxide groups remaining for the grapeseed polymer (peak at $800 \mathrm{~cm}^{-1}$ ) providing tentative evidence for this
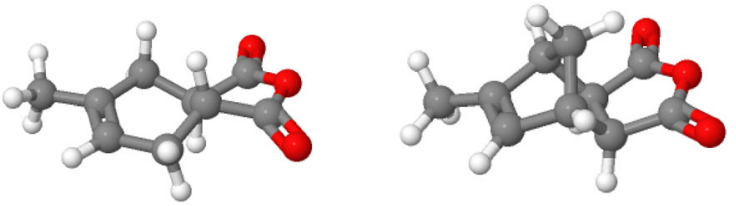

Fig. 7 Molecular structures of Aradur917 ${ }^{\circledR}$ (left) and MNA (right)

hypothesis (Fig. 8). In addition, there was no exothermic peak in the DSC analysis of the EGSO derived polymers (vide infra) indicating that curing had finished.

\section{Tensile Properties}

Polymerization reactions were performed at the temperatures previously identified in an aluminium ' $d o g$ bone' mould. The polyester resins were various shades of brown and ranged from hard brittle to soft elastic. The stress strain curves for all polymers derived from EGSO, ESBO and ERSO with both anhydrides utilizing a 1:1 E:A ratio are shown in Fig. 9. In all six cases there was no defined yield point visible indicating plastic deformation had occurred and that the polymers had fractured while still in their elastic state meaning broken pieces reverted back to their

Table 2 Stress-strain data of anhydride cured plant oil epoxy resins

\begin{tabular}{|c|c|c|c|c|c|c|c|c|c|}
\hline \multicolumn{3}{|l|}{ Polymer } & \multicolumn{3}{|l|}{ Tensile } & \multicolumn{3}{|l|}{ Thermal } & \multirow{2}{*}{$\begin{array}{l}\text { Crosslink density } \\
\left(\times 10^{-4} \mathrm{~mol} / \mathrm{cm}^{3}\right)\end{array}$} \\
\hline $\begin{array}{l}\text { Anhydride } \\
\text { (A) }\end{array}$ & $\begin{array}{l}\text { Epox. oil } \\
\text { (E) }\end{array}$ & $\begin{array}{l}\text { Ratio } \\
(\mathrm{E}: \mathrm{A})\end{array}$ & UTS (MPa) & YM (MPa) & $\mathrm{EB}(\%)$ & $T_{\mathrm{g}}\left({ }^{\circ} \mathrm{C}\right)$ & $\mathrm{T}_{-10 \%}\left({ }^{\circ} \mathrm{C}\right)$ & $\mathrm{T}_{-50 \%}\left({ }^{\circ} \mathrm{C}\right)$ & \\
\hline \multirow[t]{9}{*}{ Aradur917 ${ }^{\circledR}$} & \multirow[t]{3}{*}{ EGSO } & $1: 1$ & $12.80 \pm 1.9$ & $1005 \pm 94$ & $1.47 \pm 0.32$ & 17 & 319 & 398 & 32.9 \\
\hline & & $2: 1$ & $0.65 \pm 0.34$ & $60.10 \pm 3.0$ & $1.33 \pm 0.22$ & 3 & 359 & 396 & 23.4 \\
\hline & & $4.7: 1$ & $0.06 \pm 0.02$ & $0.50 \pm 0.19$ & $13.0 \pm 1.76$ & -17 & 367 & 411 & 12.8 \\
\hline & \multirow[t]{3}{*}{ ESBO } & $1: 1$ & $29.30 \pm 1.5$ & $1090 \pm 59$ & $4.87 \pm 0.65$ & 6 & 329 & 392 & 35.8 \\
\hline & & $2: 1$ & $1.17 \pm 0.34$ & $10.50 \pm 1.7$ & $15.2 \pm 2.44$ & -19 & 334 & 389 & 19.2 \\
\hline & & $4.4: 1$ & $0.07 \pm 0.03$ & $0.75 \pm 0.26$ & $9.86 \pm 1.21$ & -25 & 353 & 405 & 11.8 \\
\hline & \multirow[t]{3}{*}{ ERSO } & $1: 1$ & $3.94 \pm 1.83$ & $122 \pm 25$ & $11.1 \pm 6.57$ & -36 & 318 & 397 & 25.7 \\
\hline & & $2: 1$ & $0.31 \pm 0.05$ & $4.36 \pm 0.24$ & $8.54 \pm 0.95$ & -10 & 359 & 416 & 16.4 \\
\hline & & $3.8: 1$ & $0.05 \pm 0.01$ & $1.22 \pm 0.31$ & $3.90 \pm 1.39$ & -27 & 370 & 412 & 9.21 \\
\hline \multirow[t]{9}{*}{ MNA } & \multirow[t]{3}{*}{ EGSO } & $1: 1$ & $5.60 \pm 1.37$ & $468.0 \pm 72$ & $1.20 \pm 0.43$ & 62 & 311 & 401 & 16.4 \\
\hline & & $2: 1$ & $1.93 \pm 0.54$ & $30.8 \pm 12.6$ & $14.0 \pm 3.5$ & -23 & 313 & 399 & 23.5 \\
\hline & & $4.7: 1$ & $0.18 \pm 0.04$ & $1.22 \pm 0.10$ & $14.5 \pm 2.1$ & -32 & 338 & 403 & 6.0 \\
\hline & \multirow[t]{3}{*}{ ESBO } & $1: 1$ & $14.00 \pm 2.2$ & $533 \pm 39$ & $3.79 \pm 0.53$ & 54 & 317 & 407 & 23.8 \\
\hline & & $2: 1$ & $1.06 \pm 0.29$ & $11.00 \pm 3.1$ & $13.6 \pm 2.1$ & -10 & 309 & 389 & 14.0 \\
\hline & & $4.4: 1$ & $0.12 \pm 0.03$ & $0.73 \pm 0.30$ & $13.1 \pm 0.9$ & -19 & 358 & 410 & 6.2 \\
\hline & \multirow[t]{3}{*}{ ERSO } & $1: 1$ & $2.51 \pm 1.04$ & $29.7 \pm 13.6$ & $29.2 \pm 2.7$ & -12 & 294 & 403 & 17.4 \\
\hline & & $2: 1$ & $0.51 \pm 0.31$ & $40.0 \pm 28.6$ & $1.71 \pm 0.26$ & - & 338 & 395 & 9.6 \\
\hline & & $3.8: 1$ & $0.03 \pm 0.01$ & $0.64 \pm 0.13$ & $4.96 \pm 0.69$ & - & 375 & 420 & 3.7 \\
\hline
\end{tabular}

Errors are given as standard deviation. Calculated crosslinking densities of epoxy vegetable oils and anhydride polymer networks UTS ultimate tensile stress, $Y M$ Youngs modulus, EB elongation at break point 


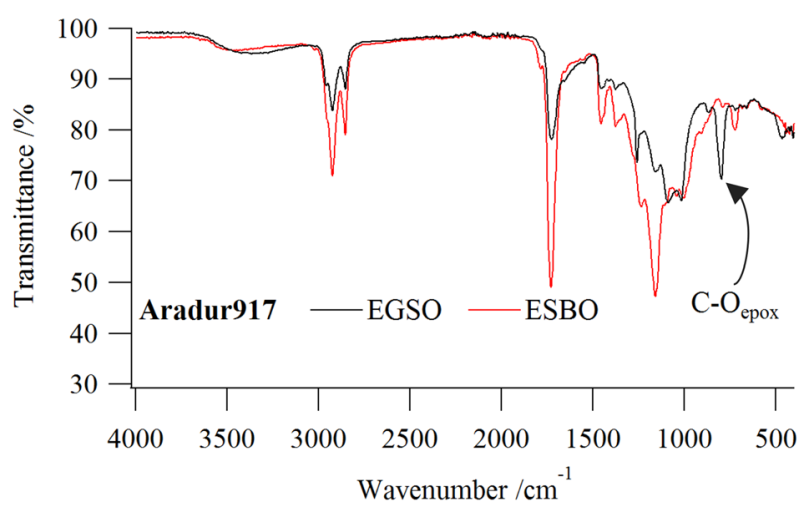

Fig. 8 FTIR analysis of ESBO and EGSO polymers cured with Aradur917 ${ }^{\circledR}(1: 1$ ratio)

original dimensions. ESBO with Aradur917 ${ }^{\circledR}(\mathrm{E}: \mathrm{A}=1: 1)$ produced the strongest polymer with an ultimate tensile stress (UTS) of $29 \mathrm{MPa}$ but this strength decreased as the ratio of anhydride hardener is decreased, E:A 2:1 $\mathrm{UTS}=1.17 \mathrm{MPa}$, E:A 4.7:1 UTS $=0.07 \mathrm{MPa}$ (Table 2).

This trend was observed for all oil/anhydride combinations and is due to the size of the polymer network. The molecular weight of these resins is governed by the amount of anhydride in the reaction and hence lower tensile strengths are observed [38-41]. Materials prepared from Aradur $917^{\circledR}$ typically had greater tensile strengths than those from MNA (1:1 E:A; EGSO 12.8 vs. 5.6 MPa, ESBO 29.3 vs. $14.0 \mathrm{MPa}$, ERSO 3.94 vs. $2.51 \mathrm{MPa}$ ). This is reflected in the crosslink density where Aradur $917^{\circledR}$ samples have consistently higher densities than MNA samples and is attributed to the increased molecular volume of MNA.

The trend in tensile strength between the three different oils is generally ESBO > EGSO $\gg$ ERSO for both anhydrides and all three E:A ratios. This pattern follows the trend in crosslinking density. Due to the fact that EGSO based polymers are less crosslinked than ESBO derived materials and that residual epoxide groups are still present it should be noted that grapeseed is not necessarily a viable

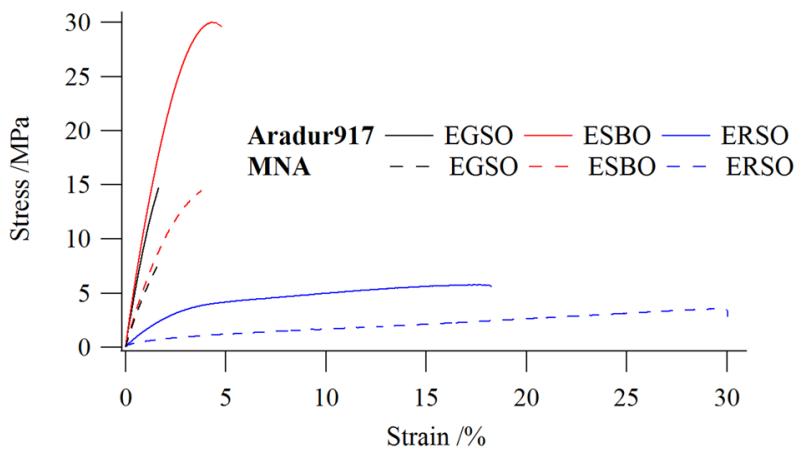

Fig. 9 Stress-strain chart of 1:1 E:A ratio option as a replacement to ESBO in high stress applications.

\section{Thermal Properties}

The glass transition temperature $\left(T_{\mathrm{g}}\right)$ is an important polymer characteristic and relates to physical properties of a material. Generally speaking, polymers with a higher crosslinking density have a higher $T_{\mathrm{g}}$, but other factors such as structure and composition can have an appreciable effect. The glass transition temperatures were measured by DSC using a combined TGA/DSC experiment, Fig. 10.

Previous work with ESBO derived epoxy resins has shown that $T_{\mathrm{g}}$ 's are lowered with decreasing levels of anhydride ( $>$ E:A ratio) $[26,42]$ and this was observed for all six oil/anhydride combinations in this study. This is attributed to a lowering of crosslink density within each series as the anhydride levels are decreased, (due to unreacted epoxides), and provides the polymer with an increase in elasticity from the linear chains. The more rigid anhydride, MNA, results in a significantly higher $T_{\mathrm{g}}$ and stiffer polyesters than for Aradur917 ${ }^{\circledR}\left(\mathrm{E}: \mathrm{A}=1: 1, \Delta T_{\mathrm{g}}\right.$ EGSO $+45^{\circ} \mathrm{C}, \mathrm{ESBO}+49^{\circ} \mathrm{C}$, ERSO $+24{ }^{\circ} \mathrm{C}$ ) as expected. The range of $T_{\mathrm{g}}$ values in this study $\left(-19\right.$ to $62{ }^{\circ} \mathrm{C}$ ) is broader than that reported for ESBO derivatives with a wide range of anhydrides $\left(19-65^{\circ} \mathrm{C}\right)$ [42] but are lower than for linseed oil derivatives [43] or commercial resins based upon BADGE [44]. EGSO derivatives generally have slightly higher $T_{\mathrm{g}}$ 's than ESBO derivatives, both of which are significantly higher than ERSO derivatives. While this doesn't parallel crosslinking density it does reflect the epoxide level of the oil monomers.

Crosslinking alone is not the most important factor in determining $T_{\mathrm{g}}$ in these systems and can be confirmed by comparing two materials with identical crosslinking densities $\left(16.4 \times 10^{-4} \mathrm{~mol} \mathrm{~m}^{-3}\right)$, ERSO:Aradur917 ${ }^{\circledR} \quad 2: 1$ $\left(T_{\mathrm{g}}=-10^{\circ} \mathrm{C}\right)$, versus EGSO:MNA $1: 1\left(T_{\mathrm{g}}=62^{\circ} \mathrm{C}\right)$.

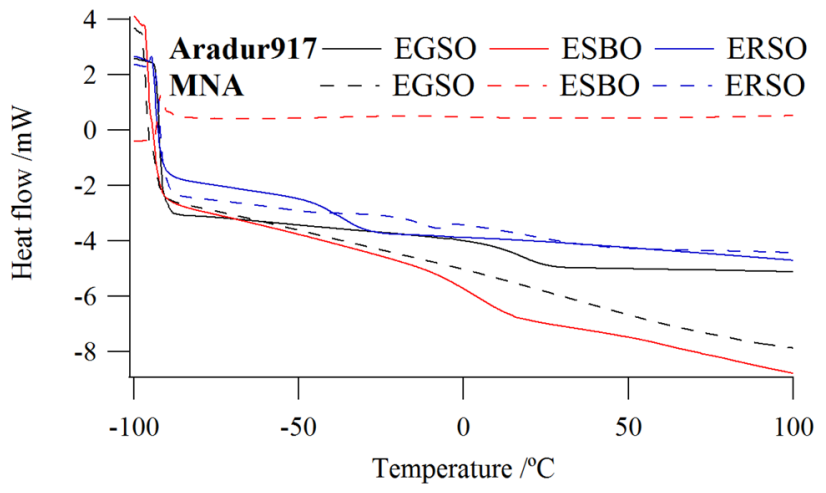

Fig. 10 DSC analysis of anhydride cured polyester resins. Only 1:1 E:A ratio shown 


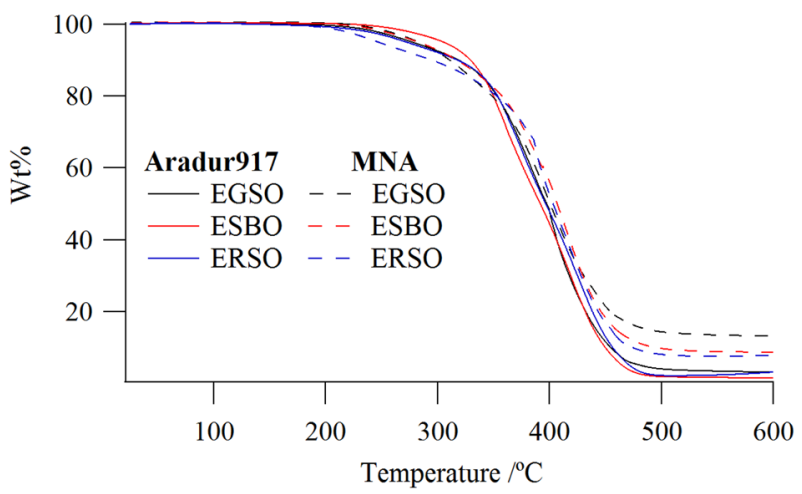

Fig. 11 TGA analysis of plant oil polyester resins. Only 1:1 E:A ratio shown

Thermogravimetric analysis (TGA) was used to determine the thermal stability of the materials, Fig. 11, data Table 2. Recent studies using 2-ethyl-4-methylimidazole as a catalyst to mediate the polymerization of ESBO and methylhexahydrophthalic anhydride (MHHPA) showed that the resins exhibited a two stage decomposition process [45]. The first stage (25 wt \%) between 200 and $300{ }^{\circ} \mathrm{C}$ was attributed to low molecular weight components, unreacted anhydride groups, and catalyst present, while the second stage (71 wt \%) between 300 and $480{ }^{\circ} \mathrm{C}$ was attributed to degradation of the soybean component. On the other hand, reaction with ESBO with a variety of other anhydrides and triethylamine as a catalyst was reported to give relatively stable materials up to $300{ }^{\circ} \mathrm{C}$ followed by a one-step degradation $300-420{ }^{\circ} \mathrm{C}$ [42]. The exception was dodecenyl-succinic anhydride (DDS) that exhibited a two-step degradation profile. These results suggest that the nature of the anhydride is important in controlling the overall initial thermal stability. Further confirmation rises from our results where materials prepared from Aradur $917^{\circledR}$ show increased initial thermal stability $\left(\mathrm{T}_{-10 \%}>8-46{ }^{\circ} \mathrm{C}\right)$ over the $200-300{ }^{\circ} \mathrm{C}$ temperature range compared to those prepared from MNA, Fig. 11. In our case, degradation of the anhydride derived segment of the polymers by a retroDiels-Alder (rDA) reaction is possible [46]. Indeed, the rDA reaction has been observed in the degradation of MNA derived polymers from petrochemical sources, where initial degradation occurs around $240{ }^{\circ} \mathrm{C}$ [47, 48]. It is likely the slightly decreased stability of the MNA derived polymers over the Aradur $917^{\circledR}$ derived ones is a reflected in the ease of rDA which is known to be more facile for bridgehead derived structures [47]. Another observation from our data highlights that an increased initial thermal stability is achieved when a lower ratio of anhydride $(>\mathrm{E}: \mathrm{A})$ is used. This provides further evidence that the initial degradation pathway reflects decomposition of the anhydride derived segments and has been observed before for ESBO derivatives.

\section{Conclusions}

A series of renewable crosslinked polyester resins were produced from epoxidized plant oils (EGSO, ESBO and ERSO) and cyclic anhydrides (Aradur917 ${ }^{\circledR}$ and MNA). The properties of the epoxy resins such as crosslink density, mechanical and thermal properties were tested in order to identify the possibility of whether grapeseed oil, a waste product from the wine industry, would be a viable replacement for soybean oil (a food crop). In terms of crosslinking density, which governs physical properties, grapeseed oil was less crosslinked than soybean polymers (for Aradur917 $^{\circledR}$ EGSO $=32.9 \times 10^{-4} \mathrm{~mol} \mathrm{~cm}^{-3}$, ESBO $=$ $35.8 \times 10^{-4} \mathrm{~mol} \mathrm{~cm}^{-3}$ ). The lower crosslink density was attributed to the higher linoleic content upon which the second epoxide becomes inaccessible for polymerisation after the first has reacted. The more rigid anhydride, MNA, results in a significantly higher $T_{\mathrm{g}}$ than for Aradur917 ${ }^{\circledR}$ however due to the lower crosslink densities in MNA derived materials their UTS is significantly lower. The EGSO/MNA $1: 1$ polymer exhibits a similar $T_{\mathrm{g}}\left(62{ }^{\circ} \mathrm{C}\right)$ to that previously reported for ESBO and phthalic anhydride $65{ }^{\circ} \mathrm{C}$ [42]. However in terms of thermal properties $\mathrm{T}_{\mathrm{g}}$ 's of grapeseed polymers were higher than soybean (for Aradur917, EGSO T $\mathrm{g}$ range -17 to $17^{\circ} \mathrm{C}, \mathrm{ESBO} \mathrm{T}_{\mathrm{g}}$ range -25 to $6{ }^{\circ} \mathrm{C}$ ). Thermal degradation showed no distinct pattern between the different oils.

ESBO derived polymers have been used mainly in nonstructural applications [24]. In polyesters ESBO has mainly been used as an additive and reactive diluent to partially replace BADGE, and as such can lower the cost and improve the processability of materials [49-51]. In conclusion it can be stated that for anhydride cured polyesters grapeseed oil would only be a sensible substitute for soybean in blending with BADGE for low stress applications or where thermal properties are more important than strength.

Open Access This article is distributed under the terms of the Creative Commons Attribution 4.0 International License (http://crea tivecommons.org/licenses/by/4.0/), which permits unrestricted use, distribution, and reproduction in any medium, provided you give appropriate credit to the original author(s) and the source, provide a link to the Creative Commons license, and indicate if changes were made.

\section{References}

1. Abas N, Kalair A, Khan N (2015) Review of fossil fuels and future energy technologies. Futures 69:31-49

2. Mythili R, Venkatachalam P, Subramanian P, Uma D (2014) Production characterization and efficiency of biodiesel: a review. Int J Energy Res 38:1233-1259

3. Biermann JU, Bornscheuer U, Meier MAR, Metzger JO, Schäfer HF (2011) Oils and fats as renewable raw materials in chemistry. Angew Chem Int Ed 50:3854-3871 
4. Corma A, Iborra S, Velty A (2007) Chemical routes for the transformation of biomass into chemicals. Chem Rev 107:2411-2502

5. Gandini A, Lacerda TM, Carvalho AJF, Trovatti E (2016) Progress of polymers from renewable resources: furans, vegetable oils, and polysaccharides. Chem Rev 116:1637-1669

6. Miao S, Wang P, Su Z, Zhang S (2014) Vegetable-oil-based polymers as future polymeric biomaterials. Acta Biomater 10:1692-1704

7. de Espinosa LM, Meier MAR (2011) Plant oils: The perfect renewable resource for polymer science? Eur Polym J $47: 837-852$

8. Xia Y, Larock RC (2010) Vegetable oil-based polymeric materials: synthesis, properties, and applications. Green Chem 12:1893-1909

9. Coles SR, Barker G, Clark AJ, Kirwan K, Jacobs D, Makenji K, Pink D (2008) Synthetic mimicking of plant oils and comparison with naturally grown products in polyurethane synthesis. Macromol Biosci 8:526-532

10. Lligadas GR, Ronda JC, Galia M, Cadiz V (2010) Plant oils as platform chemicals for polyurethane synthesis: current state-ofthe-art. Biomacromol 11:2825-2835

11. Sharma V, Kundu PP (2008) Condensation polymers from natural oils. Prog Polym Sci 33:1199-1215

12. Petrović ZS (2008) Polyurethanes from vegetable oils. Polm Rev 48:109-155

13. Meier MAR, Metzger JO, Schubert US (2007) Plant oil renewable resources as green alternatives in polymer science. Chem Soc Rev 36:1788-1802

14. Clark AJ, Hoong SS (2014) Copolymers of tetrahydrofuran and epoxidized vegetable oils: application to elastomeric polyurethanes. Polym Chem 5:3238-3244

15. Ma FR, Hanna MA (1999) Biodiesel production: a review. Bioresour Technol 70:1-15

16. Fillion B, Morsi BI (2000) Gas-liquid mass-transfer and hydrodynamic parameters in a soybean oil hydrogenation process under industrial conditions. Ind Eng Chem Res 39:2157-2168

17. Edvardsson J, Rautanen P, Littorin A, Larsson M (2001) Deactivation and coke formation on palladium and platinum catalysts in vegetable oil hydrogenation. J Am Oil Chem Soc 78:319-327

18. Crivello JV, Narayan R (1992) Epoxidized triglycerides as renewable monomers in photoinitiated cationic polymerization. Chem Mater 4:692

19. Situ Y, Hu J, Huang H, Fu H, Zeng H, Chen H (2007) Synthesis, properties and application of a novel epoxidized soybean oiltoughened phenolic resin. Chin J Chem Eng 15:418-423

20. Kessler MR, Ding R, Zhang C (2014) Reduction of epoxidized vegetable oils: a novel method to prepare bio-based polyols for polyurethanes. Macromol Rapid Commun 35:1068-1074

21. Derksen JTP, Cuperus FP, Kolster P (1996) Renewable resources in coatings technology: a review. Prog Org Coat 27:45-53

22. Karmalm P, Hjertberg T, Jansson A, Dahl R, Ankner K (2009) Network formation by epoxidised soybean oil in plastisol poly (vinyl chloride). Polym Degrad Stabil 94:1986-1990

23. Okieimen FE (2002) Studies in the utilisation of epoxidized vegetable oils as thermal stabiliser for poly(vinyl chloride). Ind Crop Prod 15:71-75

24. Wang R, Schuman TP (2013) Vegetable oil-derived epoxy monomers and polymer blends: a comparative study with review. Express Polym Lett 7:272-292

25. Karger-Kocsis J, Grishchuk S, Sorochynska L, Rong MZ (2013) Curing, gelling, thermomechanical and thermal decomposition behaviours of anhydride-cured epoxy DGEBA/epoxidised soybean oil compositions. Polym Eng Sci 54:747-755

26. España JM, Sánchez-Nacher L, Boronat T, Fombuena V, Balart R (2012) Properties of biobased epoxy resins from epoxidised soybean oil (ESBO) cured with maleic anhydride (MA). J Am Chem Oil Soc 89:2067-2075

27. O'Brien RD (2003) Fats and oils: formulating and processing for applications, 2nd edn. CRC Press, Boca Raton, FL

28. Larock RC, Andjelovic VM, Henna P, Li F (2005) Novel thermosets prepared by cationic copolymerization of various vegetable oils-synthesis and their structure-property relationships. Polymer 46:9674-9685

29. Kamel SB, Dawson H, Kakuda Y (1985) Characteristics and composition of melon and grapeseed oils and cakes. J Am Oil Chem Soc 62:881-883

30. Srivastava A, Prasad R (2000) Triglycerides-based diesel fuels. Renew Sust Energy Rev 4:111-133

31. Porto CD, Decorti D, Natolino A (2013) Effect of commercial enzymatic preparation with pectolytic activities on conventional extraction and ultrasound-assisted extraction of oil from grapeseed (Vitis vinifera L.). Int J Food Sci Technol 48:2127-2132

32. Fantozzi P, Betschart AA (1979) Development of grapeseed protein. J Am Oil Chem Soc 56:457-459

33. United Nations Food and Agriculture Organisation. http://fao stat3.fao.org/faostatgateway/go/to/browse/Q/QC/E. Accessed 20 July 2016

34. Cai C, Dai H, Chen R, Su C, Xu X, Zhang S, Yang L (2008) Studies on the kinetics of in situ epoxidation of vegetable oils. Eur J Lipid Sci Technol 110:341-346

35. Sharma S, Kim JR (2012) The development and comparison of bio-thermoset plastics from epoxidised plant oils. Ind Crop Prod 36:485-499

36. Martini DS, Braga BA, Samios D (2009) On the curing of linseed oil epoxidized methyl esters with different cyclic dicarboxylic anhydrides. Polymer 50:2919-2925

37. Pan X, Sengupta P, Webster DC (2011) High biobased content epoxy-anhydride thermosets from epoxidized sucrose esters of fatty acids. Biomacromol 12:2416-2428

38. Rocks J, George GA, Vohwinkel F (2003) Curing kinetics and thermomechanical behaviour of co-anhydride cured aminoglycidyl epoxy resins. Polym Int 52:1758-1766

39. Stern C, Frick A, Weickert G (2007) Relationship between the structure and mechanical properties of polypropylene: effects of the molecular weight and shear-induced structure. J Appl Polym Sci 103:519-533

40. Hallam MA, Pollard G, Ward IM (1987) Relationship between tensile strength and molecular weight of highly drawn polyethylenes. J Mater Sci Lett 6:796-976

41. Montserrar S, Flaque C, Calafel M (1995) Influence of the accelerator concentration on the curing reaction of an epoxyanhydride system. Thermochim Acta 269:213-229

42. Gerbase AE, Petzhold CL, Costa APO (2002) Dynamic mechanical and thermal behaviour of epoxy resins based upon soybean oil. J Am Oil Chem Soc 79:797-802

43. Miyagawa H, Mohanty AK, Misra M, Drzal LT (2004) Thermophysical and impact properties of epoxy containing epoxidized linseed oil, 1. Anhydride-cured epoxy. Macromol Mater Eng 289:629-635

44. Stevens GC, Richardson MJ (1983) Factors influencing the glass transition of DEGBA-anhydride epoxy resin. Polymer 24: 851-858

45. Tan SG, Chow WS (2011) Curing characteristics and thermal properties of epoxidized soybean oil based thermosetting resin. J Am Oil Chem Soc 88:915-923

46. Vijayakumar CT, Leder K, Kramer A (1991) Thermogravimetric study of nadic-, methylnadic-, and allylnadic-bisimide monomers. J Polym Sci Part A Polym Chem 29:929-931

47. Freeman ES, Becker AJ (1968) Thermal degradation of nadic methyl anhydride-crosslinked novolac epoxy resin. J Polym Sci Part A 6:2829-2851 
48. Rickborn B (1998) The retro-diels-alder reaction. Part 1. C-C dienophiles. Org React 52:1-393

49. Gupta AP, Ahmad S, Dev A (2011) Modification of novel biobased resin-epoxidized soybean oil by conventional epoxy resin. Polym Eng Sci 51:1087-1091

50. Czub P (2006) Characterization of an epoxy resin modified with natural oil-based reactive diluents. Macromol Symp 245-246: $533-538$
51. Rösch J, Mülhaupt R (1993) Polymers from renewable resources: polyester resins and blends based upon anhydride-cured epoxidized soybean oil. Polym Bull 31:679-685 